\title{
Reconfiguring the Shipping News: Maritime's hidden histories and the politics of gender display
}

\author{
Pam Meecham \\ Institute of Education, University of London, UK
}

This paper discusses the book Hello Sailor! The Hidden History of Gay Life at Sea published in 2003 by Paul Baker and Jo Stanley re-interpreted as a landmark temporary, exhibition Hello Sailor! Gay Life on the Ocean Wave at Merseyside Maritime Museum, Liverpool from where it will travel in 2007 to a number of other maritime museums. Based largely on oral history interviews and part of a hidden histories project, the book recovers the previously repressed histories of gay sailors in the 'gay heaven' of the merchant navy. It historically spans, roughly mid to late twentieth century. This paper seeks to explore the construction of gay seafarers presented in the book and latterly through museum display. It reveals what can be understood about the re-presentation of gendered identities and relations through the celebration of camp and cross-dressing. Baker and Stanley draw on queer theory rather than gay and lesbian studies and argue that the recovered history is not about civil rights but is rather 'a politics of carnival, transgression and parody' (Baker and Stanley, 2003, p. 19). The book and to a greater extent the exhibition however only partially unravel two important issues: sex and misogyny. This paper asks what light 'hidden histories', re-presented in museums can shed on gender and sexual relations in the present.

\section{Image}

Balmoral or the fruit locker cabin at Merseyside Maritime Museum 2007copyright Pam Meecham 
At least since Anderson's 1999 dcms report A Common Wealth: Museums in the Learning Age museum visiting has become a mandatory part of the school curriculum. While such visits play an important role in presenting primary documents and artefacts to reinforce the paradigms played out in received histories, the representation of hidden histories has the potential to derail orthodoxies and, if not induce widespread moral panic, at least offer a glimpse of alternative ways of being in the world. Artefacts are expressions of society and culture, however representing a little told history, the case in point that of gay mariners, is not simply a question of recovery and display. Exposure to potential stereotypes can also lead to conformation of traditional histories. Museums are powerful tools in the formation of national identities: they validate and dismiss in about equal measure (Coombes, 1988). The maritime displays of colonial acquisition and battles contribute to our 'collected memory' of what is worth remembering and by extension what is not (Young, 1993). Multiculturalism/interculturalism and postcolonial studies, for instance, have witnessed a fruitful reconfiguration of maritime displays on the previously repressed or sanitised history of slavery. Exhibiting sexuality in a maritime museum, however, is proving a complex undertaking. The touring exhibition Hello Sailor! Gay Life on the Ocean Wave is not a paying exhibition and is therefore open to all whether directed or just wandering in the interpretive spaces of the museum.

Published in 2003 Paul Baker and Jo Stanley's Hello Sailor! The Hidden History of Gay Life at Sea was re-presented as a landmark-touring exhibition Hello Sailor! Gay Life on the Ocean Wave at Merseyside Maritime Museum. With Jo Stanley and Charlotte Stead curating it was initially shown from 25 August 2006 to 25 March 2007 in Liverpool and in Southampton until September 07: the rest of its tour uncertain, an indication of the complexity of bringing to light a repressed history into the resolutely hetronormative spaces of maritime museums. Any book's translation into an exhibition is of course a deeply complex problem: the transition for text to visual realisation requiring objects and compelling materials and often a subsequent loss of scholarship. However Hello Sailor! Gay Life on the Ocean Wave as the first exhibition of its kind carried a pioneering burden evident in sentimentalism and flirting with perceived gay values at the expense of debate. Interviewed, the museum curator Charlotte Stead, was aware that the exhibition was celebratory rather than discursory but groundbreaking nonetheless (Interview with author $20^{\text {th }}$ March 2007). My remarks are not intended to undermine a 
determined attempt by a museum to put its windswept history in order but rather to explore further possibilities.

The book is '...tribute to the thousands of brave gay seafaring men who persisted -and sometimes had fun' (Baker and Stanley, 2003, frontispiece). Part of a hidden histories project it is principally based on nine oral history interviews and archive material: its origins in a $\mathrm{PhD}$ thesis. It recovers the previously repressed lives of gay sailors who found sanctuary in the so-called 'gay heaven' of the merchant navy between the austerity years of 1950s England to the legislatively less punitive 1980s. The exhibition covers a period before the term gay had currency and homophobia was supported by pathologising and retaliatory legislation with origins going back to the Buggery Act of 1533, un-repealed until 1967. A generation of seafarers, most typically employed in catering and hospitality on the P\&O lines, found 'floating havens' on gay friendly ships where their attention to domestic detail and exuberant lifestyles were not merely patronised and tolerated but at times, according to the book and subsequent exhibition, openly celebrated. Adept at teamplaying, gay stewards in particular were valued for their professional competence.

Although Baker and Stanley's project was to uncover a covert history I want to look at the margins of such a history and ask about the form of resistance that a counter-culture took during this period. For instance, the book raises, although does not entirely answer important issues such as 'How could gay men at sea be tolerated when women aboard were superstitiously seen as wreckers?' (Baker and Stanley, 2003, p. x). The authors do tacitly contextualise the gay seafarer by addressing the issue of women generally, suggesting that 'Removing women from the field of study...obscures the connections between masculinity and social power' (Baker and Stanley, 2003, p.20) but never offers convincing evidence of how that works in practice. A history of gay sailors is not obliged to include any commentary on women but the book and subsequent exhibition do shoehorn gender relations into the picture: they have therefore the potential to enhance our understanding of the construction of gendered identities through the celebration of camp, cross-dressing and gay domestic virtue. As Harris suggests 'Gender is intimately bound up with socio-sexual identity and the range of characteristics associated, at any particular time, with the states of being masculine or feminine' (Harris, 2006, p. 128).

What occupies me here is how women in particular and school children in general make sense of the display of a recent historic period, its 
language and attitudes. This paper seeks to explore therefore gender and sexual relations that are a precondition of the performativity of drag and look at what is lost in translation between book and its metamorphosis in the battleship grey masculinized spaces of maritime museums.

Importantly Baker and Stanley draw on queer theory rather than gay and lesbian studies and argue that the recovered history is not about civil rights but is rather 'a politics of carnival, transgression and parody' (Baker and Stanley, 2003, p. 19). However while carnival, transgression and parody echo politely through the exhibition it errs on the side of civil rights and the politics of inclusion ironically as it fails to unravel the relative transparency of the book on two important levels: sex and misogyny.

The book emphasised the coded language of polari termed by linguists such as Halliday an anti-language that enabled a secret fraternity to communicate outside of 'normative' language and to construct a world built on shared values (Baker and Stanley, 2003, pp. 83-4). Historically well-researched the authors go to some lengths to recover the ways that polari was specifically used and developed onboard merchant ships. Although the subject of a longer discussion it is the frequency of references to palone (women) and the use of female names (affectionate, mocking and derogatory) that are the hallmark of polari exchanges. The book at least is clear that polari became increasingly unpopular and unfashionable with gay culture post 1980s due to its sexist and racist undercurrents and under an increasingly theorised gay and lesbian studies that also questioned stereotypes of butch and femme and the dangers of ghettoisation inherent in forms of cross-dressing and secret language. While polari and cross-dressing are well-explored in the book they are only part of the complex history presented. In the exhibition however, they are overtly represented and yet under-theorised in relation to contemporary visitors.

Female drag and cross-dressing, were indispensable elements in the regular cabarets that punctuated life at sea. The theatricality of the regular cabarets was, unsurprisingly, given primacy in the exhibition with its need to capture visually and audibly period detail. Closely identified with camp culture, drag and squabbling rival queens, it is Chapter 5's 'Sequins, Satins and Stilettos' that translated makes so compelling an eye-witness account of a counter-culture creating strategies to gain attention and undermine a repressive society. The drama of Masked Ball invitations give telling glimpses of routines pitted against normative behaviours. 
The epoch comes to life in the exhibition in Balmoral, a mock-up cabin, with tacked on beefcake posters of Reynolds, Newman and Hudson, and other iconic gay paraphernalia: Wizard of $\mathrm{Oz}$, film-stills and a locker door photograph of Kenneth Williams in a sailor's uniform. A kitsch tangerine, sequined and ostrich feathered ball-gown hangs incongruously in the regulation closet. The sequined gown however, is as close to carnival as the exhibition manages. Set within the stern spaces of maritime display, the exhibition is understandably muffled although the designer's obligatory pink candy- striped display boards stand in stark contrast to its seafaring surrounding render its temporary existence even more ephemeral. Nonetheless, the passionate and bawdy exchanges, descriptions of affairettes and raunchy asides that illuminate the book are reconfigured in Kenneth Williams' innuendo and adept use of polari in audio clips of the 50s and 60s radio programme Round the Horn and film footage of 1962's Pinewood Studio film Carry on Cruising. The book turned on its ribald retelling of the joys of uncensored casual sexual encounter, cross-dressing, camp laughter and gay porn away from a censorious England. Although the exhibition is frank about some of the bawdier aspects of life on a gay heaven, it remains rather 'sanitised' preferring to pursue a human rights/citizenship approach that emphasises the tolerance and acceptance that gay people found at sea. It relates tales of long-term relationships developed at sea that were celebrated more recently in civil partnership. A benign interactive word game translating less contentious polari also fails to convey the subversive, inflammatory and discriminatory aspects of the secret language. While there is no dressing-up box there are touch-screens, interactive games and audio wands indicating an inclusive and cross-generational educational approach.

I wish to turn in greater detail to representation of campness. Camp ${ }^{1}$ is usually defined as a performance or 'form of cultural appreciation' that is 'non-serious' in expression (Butt, 2004, p. 329). In the context of the 50s 60s and 70s, the most significant period under review, camp can be seen simply as an assault on normative gender constructions that were

\footnotetext{
${ }^{1}$ Camp is described as 'To speak, act, or in any way attract or attempt to attract attention, especially if noisily, flamboyantly, bizarrely, or in any other way calculated to announce, express, or burlesque one's own homosexuality or that of any other person. As a NOUN, camp refers to such flamboyance or bizarrerie of speech or action, or to the person displaying it. The VERBAL NOUN, camping, is very common; it should be noticed that camping is largely a practice of male homosexuals, and is not very common among Lesbians'. ADJECTIVE: Campy (original emphasis, fonts and case) Cameron, Deborah and Don Kulick (Eds) (2006) The Language Sexuality Readerpp22, Abingdon: Routledge
} 
particularly polarised by post-war rejection of Rosie the Riveter to feminised, fecund women in the home and returning war heroes expropriating their naturalised position in the workplace. It can therefore be argued that parody of the normative female (and camp had to play on stereotype to be understood) threw into theatrical relief post-war assigned gender-roles.

However, theatricising and playfulness are the hallmarks of camp. According to Susan Sontag the "whole point of camp was to dethrone seriousness' (Sontag, 1964, p. 527). Famously she asserts camp's triumph of style over content, maintaining 'the Camp sensibility is disengaged, depoliticized-or at least apolitical' (Sontag, 1964, p. 517). Sontag is also at pains to stress that although in the vanguard and its most 'articulate audience' 'it's not true that Camp taste is homosexual taste, [although] there is no doubt a peculiar affinity and overlap'. One visitor at the Hello Sailor exhibition was quick to point out the collapsing of gay and camp in the exhibition: a point to which I'll return.

What occupies me here is how a pyrrhic victory is to be avoided if camp is merely an apolitical parody of the trivialising of excesses of female dress and behaviour. Of course gay cross-dressing can be understood as an affectionate, generous gesture towards another under represented group. However, if only theatrical and not to be taken seriously what was the point of camp and where is it positioned now in public exhibitions? How will it be read and interpreted by young visitors to the museum? Hayes for instance suggests quite contrary to Sontag's notion of a benign 'sweet cynicism' (Sontag, 1964, p. 530) ... the humour in Gayspeak, especially camp, (while not reducing it to an exclusively gay phenomenon or gay to camp) is often cynical because it is based on a serious relation to the world. Therefore, in the social setting, Gayspeak implies that there is always a vast gulf between what people pretend to be and what they are (Hayes, 2006, p. 70).

Another issue to arise out of the exhibition is why, in an arena where women were almost entirely absent, camp culture (gay and straight) singled out as a form of resistance or derision the most despised of women, the domesticated housewife and the gold digger, diva or vamp? ${ }^{2}$ The exhibition is frustratingly mute on the subject and the book somewhat cursorily attributes hostile attitudes to women within the context of competition for men (many heterosexual men had gay sex on ships) and by the 1980s, jobs.

\footnotetext{
${ }^{2}$ See esp. 'Gayspeak': A Response, p81 in Cameron, Deborah and Don Kulick (Eds) (2006) The Language Sexuality Readerpp22
} 
Is camp to be read as apolitical in the context of the exhibition, as only frivolous because it never overtly questions the roles we've been assigned and entails no criticism of them? Is the camp on offer, apolitical falling into what was termed 'ahistorical kitsch' (Robertson, 1996, p. 4)? Or with gender variant visual and performance artists such as Del LaGrace Volcano www.dellagracevolcano.com has the landscape of gender expression changed. Changed to such an extent that rather like recent Emmy winning BBC television's, 21 st century detective Sam Tyler in Life on Mars: who 'had an accident and woke up in 1973' what becomes apparent in this particular exhibition and book is the social and historical construction of language, gender and sexual identities. The exhibition is also a reminder that film theorist Laura Mulvey's early 1989 work on scopophilia (the pursuit of visual pleasure) that had argued that women took up the 'universal' position of the male viewer in order to gain any active pleasure in looking, had been overturned by theorists such as Irigaray (1985). Irigaray reminded us that subversive watching from a range of positions had always taken place and that the act of looking cannot be universalised.

The lack of debate in the exhibition around the reception of crossdressing and camp laughter that commands most attention would seem to indicate an acceptance that cross-dressing and role play are merely vehicles for fun. At the risk of being joyless and censorial can a case be made for a more radical camp? Rather than being seen as complicit with the dominant view of gender and sexually assigned roles does the fruit locker's celebration of tangerine taffeta do more than reinforce stereotypes of both gay men and women: the possibility of social satire lost in innuendo, double entendre and some badly dressed queens.

Several leading feminist theorists such as Judith Butler and Mary Ann Doane, have drawn out camp's subversive potential through its form of gender parody. Through a combination of parodic mimicry and misrecognition such theorists suggest the female spectator recognizes herself in camp images but also misrecognizes herself and therefore is made aware that the self is always under construction: there is no essential self prior to the mimicry. Under this theoretical position therefore, the Del Monte divas' in Hello Sailor call into question the regulatory practices of identity itself. However as Butler also points out in Bodies that Matter drag although revealing through performativity the construction of gender identity, it does nothing to dismantle it. And it was the charge of apoliticality as well as misogyny and racism that saw the enthusiasm for camp and drag wane in the more politically aware 80 s. 
Feminism and gay politics may have shared agendas in pitting themselves against the normalising strategies of identity constructions but there are also differences visible in the weekly drag act at the maritime museum. A drag artist was employed to re-enact Jo Stanley's script 'Nothings Queer Until You've Left That Pier' based on a close reading of the oral history interviews. The review is set on a Saturday afternoon in July 1967 as entertainment to celebrate the passing of the new Sexual Offences Act permitting limited homosexuality. It involves Dazzling Denise, aka Dennis, a dining room steward transforming himself into cabaret star Denise. During the 1960s acting out could be read as a defiant gesture and certainly challenged notions of stable masculine and feminine identities. What is less comfortable is the hostile ambivalence to women evident in the language of the period: the fag hag and fish. Other stereotypes can also be reinforced as the ritual of making-up and unmaking reveals what men and women are not, as well as what they are constructed to be. The stereotype of the effeminate homosexual man and diva are both revealed and concealed. The script is quick to point out that dressing in women's clothes was enjoyed by straight and gay men although just why remains unresolved.

Recent feminist theory has moved away from the radical potential of cross-dressing and transvestism and reinvested in an earlier Joan Riviere's 1929 essay 'Womanliness as a Masquerade' to consider female masquerade that seems to offer a more radical parodic potential. Writing of Mae West, Pamela Robertson reiterates the commonly held conviction that West 'represents a female displaying a male displaying a female' in brief 'a female female impersonator'... taking on 'an instance of masculine characteristics, as a "phallic woman" and as a "female displaying a male displaying a female"" (Robertson, 1996, p. 33).

From a feminist perspective Robertson offers a further reading than that of a masculine performance of the female. Robertson argues that through burlesque Mae West parodies the male drag of women 'by replacing and displacing it with the hyperbolization of the feminine through masquerade-and not because West represents masculine characteristics behind the female masquerade' (Robertson, 1996, p. 33). The distinction is an important one in reinvesting and recuperating an earlier female aesthetic and a specifically feminine form of aggression rather than merely conventionally engaging in the mimicking of female dress, behaviour and body language. Robertson suggests the inversion of West as a woman parodying gay camp's performance of women, is a feminist strategy. It certainly avoids the self-loathing or at best self-deprecation that could be seen as the result of impersonating a male impersonating a 
female. The transgressive potential for feminist and gay culture in West's performance therefore lies via the female impersonation of the drag performance so that 'the joke is not the women [which is of course what is so uncomfortable about drag for the female spectator] but the idea that an essential feminine identity is always a masquerade or impersonation' (Robertson, 1996, p. 33).

But there is another aspect to a feminine performance rather than a masculine impersonation of a male impersonating a women and that is the visible transgressing of fixed sexualities that women such as West complicated offering a wider range of possibilities than traditional gay camp parodies of the diva reinforced in Hello Sailor. Even with reservations about Roberson's reading of West it problematises drag performance allowing a space (albeit knowing and ironic) to indulge in pleasure in looking rather than merely being complicit in ridicule. And despite Robertson's attempt to retrieve West from a deficit model, it is West's 1970s definition of camp as the 'kinda comedy that makes fun of me' that resonates most with the exhibition.

The excesses of drag represented in the exhibition's fruit locker, I suggest, has the potential to be read as subversive rather than apolitical if curated with greater complexity as while camp may appropriate and lay bare stereotypes it also perpetuates them. If as Robertson for instance argues, 'camp is both a mode of excess and a method of containment' and crucially that "camp depends on our simultaneously recognizing stereotypes as stereotypes to distance ourselves from them and at the same time recognizing and loving, the hold and power those stereotypes have over us' (Roberson, 1996, p. 142) the exhibition's historic location has huge untapped potential. The display of camp and cross-dressing and the parodist's use of women needs more considered context in exhibition display. For visiting school parties who may well not have access to irony and humour and see gay and camp as inter-changeable, and women as 'less than' there is huge potential for opening up the exhibition to a wider range of interpretation.

In a period when interpretation in museums, away from the didacticism of authorial control (Barthes, 1977; Denzin, 1989; Falk and Dierking, 1992) has sought new ways to interpret collections and offer a range of meanings, audiences are often sophisticated, used to high levels of information and questioning. Moreover if the museum is to move to Witcomb's reimagined museum beyond the mausoleum, to engage in reconciliation between conflicting and diverse histories (Witcomb, 2003) 
this exhibition could provide a much-needed debating platform. However using the comment book as a research tool at two of the exhibitions venues, a discursive space may not be an easy option and could also account for some of muted celebrations.

\section{The Comment Book}

Homosexuality in the Merchant and Royal Navy was only legalised in 1999 after an intervention by the European Court of Human Rights. And the rawness of injustice pitted against Royal Naval moral convictions can be read out of the publicly available visitor book. Congratulating the museum on the exhibition, Jacqui from the Wirral wrote 'I was kicked out of the Royal Navy for being gay, so its nice to see a positive slant. Pity it didn't extend to the Royal Navy! Well done'. Another signatory in the Merseyside Maritime Museum's comment book (although supporting the exhibition) observed that while very strong on camp 'that gayness and camp are quite separate things'. He would have liked an exploration of that...he was also interested to see recorded historic pockets of tolerance. It is noteworthy however that outing gay sailors could still arouse extreme reaction. Another visitor wrote... 'totally unacceptable and unlawful [legalization of homosexuality in the navy] when introduced (wrongly) in 1999 it was not accepted by many/majority of sailors and a high percentage left the Navy because of this. To this day it does not work and should not have been allowed'. The visitor book's bold and capitalised: NO SODOMY IN OUR MUSEUM was left uncensored. The proprietorial OUR MUSEUM inconclusive but visceral evidence of sedimented attitudes, was backed by others convinced that the exhibition was evidence of a slur on the war dead. Although a museum there is continuity with lived naval experience through the use of ex-merchant seamen as staff. My guide on one visit distanced himself from the exhibition with 'I don't go in there much' [the Hello Sailor exhibition] but he was quick to defend the right of gay mariners to have their history told. Other mariners writing in the book were less convinced of the accuracy of the history as they had not personally been aware of any floating gay havens. Visiting the Southampton exhibition, Becky Knell, an MA student noted there had been official complaints and articles in the local paper and the charge of 'morally damaging' levelled by one parent visiting with a child. Mirroring visitor comments at the Liverpool exhibition, the Southampton book was polarised between hostility; 'unbelievable' 'very offensive' 'pointless' to supportive; 'Brilliant and long overdue'. The comments were also 'mingled with sadness' and an urging of the museum to look further for such stories and more requests to include gay life in the Royal Navy (Rebecca Knell emails 4 June and 
15 July 2007). Commentary also revealed that overseas visitors in particular were pleasantly surprised at the level of tolerance to the exhibition observing that it was a brave gesture. However at a second visit to the exhibition, Knell found a sign at the entrance suggesting it was suitable only for those over 14.

Finally, one strength of the exhibition, unavailable to a book, was to use sound as well as visuals. And there were tears as well as laughter, and the strength of the exhibition lay in the audio wands and interactive touch screens that did much to retrieve and consolidate this little discussed history. The technology brought to life the oral history interviews where beyond the humour, the resignation and despair expressed by several participants is palpable. Listened to as pod casts from the website or in the exhibition, the spoken word with intonation and modulation, brings to life the printed word. Plundering the past for positive images, while an important strategy for the recognition of the contribution of underrepresented peoples should not take the place of more nuanced histories. Important as it is to record such histories a more discursive debate in the exhibition would render it a powerful tool for understanding the construction of gender and sexualities as well as mudding the waters of orthodox, sanctioned maritime history. The education and curatorial staff at the Merseyside Maritime Museum are museum people rather than naval and would like to see a permanent exhibition. The exhibition and work on the history of Gay Mariners is a work in progress and as such pioneering in its ambition and already has offered a glimpse of alternative ways of being in the world. Jo Stanley, for instance, is still collecting further oral histories. What form further exhibitions and a permanent exhibition take will be interesting. The current show costing only $£ 25$, 000 is a low budget affair with something of the B-movie about it. A future exhibition will need greater complexity and education programming if its full potential is to be uncovered.

\section{References}

Anderson, D. (1999) A Common Wealth: Museums in the Learning Age Museum (London, dcms Stationary Office).

Baker, P. \& Stanley, J. (2003) Hello Sailor! The Hidden History of Gay Life at Sea (Harlow, Longmans). 
Barthes, R. (1977)[1968] Death of the Author, in: Image-Music-Text (New York, Hill \& Wang).

Brown, L. (2000) (Ed.) Cassell's English Dictionary (London, Cassell and Co).

Butt, G. (2004) How New York queered the idea of modern art, in: P. Wood (Ed.) Varieties of Modernism (New Haven and London, Yale University Press in association with The Open University), 315-337.

Butler, J (1997) Bodies that Matter: On the Discursive Limits of "Sex" (New York, Routledge).

Coombes, A. E. (1988) Museums and the Formation of National and Cultural Identities, Oxford Art Journal 11:2 (Oxford, Oxford University Press), 57-68.

Denzin N.K. (1989) Interpretive Interactionism (Newbury Park, CA: Sage).

Falk, J.H. \& Dierking, L.D. (1992) The Museum Experience (Washington D.C., Whaleback Books).

Harris, Jonathan (2006) Art History: The Key Concepts (Abingdon, Routledge).

Irigaray, L. (1985) [1975] Speculum of the Other Woman (Ithaca NY, Cornell University Press).

Riviere, J. (1929) (1986) Womanliness as a Masquerade, in: V Burgin. D. James, \& C. Kaplan (Eds) Formations of Fantasy (London, Methuen).

Cameron, D. \& Kulick D. (Eds) (2006) The Language Sexuality Reader (Abingdon, Routledge).

Hayes, J. J. (1981) (2006) 'Gayspeak' in D. Cameron, \& D. Kulick (Eds) The Language Sexuality Reader (Abingdon, Routledge), 68-85.

Knell R. email 4 June 2007

Mulvey, L. (1989) Visual and Other Pleasures, (Bloomington Ind, Indiana University Press).

Sontag, S. (1964) Notes on “Camp”, (Partisan Review, vol.3), 515-30.

Robertson, P. (1996) Guilty Pleasures: Feminist Camp from Mae West to Madonna, (Durham, NC: Duke University Press).

Russo, V. 1976 Camp The Advocate, 19 May in: Levine, M.P. (Ed) Gay Men: The Sociology of Male Homosexuality (New York: Harper \& Row), 205-210.

Witcomb, A. (2003) Re-Imagining the Museum: Beyond the Mausoleum (Abingdon, Routledge).

www.dellagracevolcano.com

Young, J. (1993) The Texture of Memory: Holocaust memorials and meaning (New Haven, Conn., Yale University Press).

Interview

Interview at Merseyside Maritime Museum with Charlotte Stead curator of Hello Sailor! Gay Life on the Ocean Waves $20^{\text {th }}$ March 2007. 